\title{
Türkiye'de Marka Sadakati Konulu Lisansüstü Tezlerin ve Makalelerin Bibliyometrik Profili
}

\section{Bibliometric Profile of Postgraduate Theses and Articles on Brand Loyalty in Turkey}

\author{
Saadet Pınar Temizkan (1) a \& Derya Avcı (1) b, * \\ ${ }^{a}$ Department of Tourism and Management, Faculty of Tourism, Eskişehir Osmangazi University, Eskişehir, Turkey \\ ${ }^{b}$ Department of Tourism and Management, Institute of Social Sciences, Eskişehir Osmangazi University, Eskişehir, Turkey
}

\begin{abstract}
Özet
Bibliyometrik analiz, akademik kurumların, kişilerin ve dergilerin bilimsel performansını ortaya koymayı amaçlayan, bir bilim dalındaki veya araştırma alanındaki gelişmelerin analiz edilmesinin yanı sıra ülkeler ve kurumlar arasında karşılaştırma yapmaya olanak sağlayan nitel bir araştırma yöntemidir. Bu araştırmanın amacı; Türkiye'de marka kavramı konulu lisansüstü tezlerinin ve makalelerin bibliyometri yöntemine göre incelemektir. Bu amaçla, Yükseköğrenim Kurulu Başkanlığı (YÖK) Ulusal Tez Merkezi veri tabanında kayıtlı olan toplam 168 lisansüstü tezi ve Türkiye Akademik Arşivi (Harman) veri tabanından elde edilen 141 makale incelemeye tabi tutulmuştur. Toplanan veriler bibliyometrik analiz yöntemi ile sınıflandırılmıştır. Araştırmada kullanılan parametreler ise hangi yılda yayınlandığı, üniversitesi, anabilim dalı, dili, dergi ismi, araştırma yöntemi, örnekleme seçme yöntemi, örneklem grubu ve araştırma modelinde marka sadakati kavramı ile ilişkisi incelenen kavramlar şeklindedir. Araştırma sonuçlarına göre marka sadakati kavramı ile ilişkisi en çok incelenen kavramlar “Marka Güveni” (40), “ilişki Eğilimi” (22), “Marka Aşkı” (21), “Marka Kişiliği” (19) ve "Güven” (10) kavramlarıdır. Ayrıca araştırmanın diğer sonuçlarına göre marka sadakati kavramı ile ilgili en çok makale türünde ve Türkçe dilinde çalışma yayınlanmıştır. Bununla beraber en fazla tezin yayınlandığı üniversite ve anabilim dalı sırasıyla Marmara üniversitesi ve işletme anabilim dalıdır. Çalışmalarda nicel araştırma yöntemlerinin ve kolayda örnekleme seçme yönteminin ve veri toplama yöntemi anket tekniğinin daha fazla kullanıldığı saptanmıştır.
\end{abstract}

Anahtar Kelimeler: Marka Sadakati, Bibliyometri, Makaleler, Lisansüstü Tezler.

\begin{abstract}
Bibliometric analysis is a qualitative research method that aims to reveal the scientific performance of academic institutions, individuals and journals, and allows to make comparisons between countries and institutions, as well as analyzing developments in a science or research field. The purpose of this research; To examine the postgraduate theses and articles on the concept of brand in Turkey according to the bibliometric method. For this purpose, a total of 168 graduate theses registered in the National Thesis Center database of the Council of Higher Education (YÖK) and 141 articles obtained from the Turkish Academic Archive (Harman) database were examined. The collected data were classified by bibliometric analysis method. The parameters used in the research are in the form of the year it was published, the university, the department, the language, the name of the journal, the research method, the sampling selection method, the sample group, and the concepts examined in relation to the concept of
\end{abstract}

\footnotetext{
* Corresponding author:

Avcı Derya is a doctoral candidate in. Department of Tourism Management, Institute of Social Sciences, Eskişehir Osmangazi University, Her research interests include the Marketing and Gastronomy.. He has lived in Bursa and studied in Eskişehir, Turkey.

Email:deryayklavci@gmail.com
} 
brand loyalty in the research model.According to the results of the research, the most examined concepts in relation to the concept of brand loyalty are "Brand Trust" (40), "Relationship Tendency" (22), "Brand Love" (21), "Brand Personality" (19) and "Trust" (10). are concepts. In addition, according to the other results of the research, the most number of articles related to the concept of brand loyalty and in Turkish language were published. However, the university and the department in which the most theses are published are Marmara University and the Department of Business Administration, respectively. In the studies, it was determined that quantitative research methods, convenience sampling method and survey technique as data collection method were used more.

Keywords: Brand Loyalty, Bibliometrics, Article, Postgraduate Theses.

DOI: https://doi.org/10.29329/jtm.2020.289.5

\section{GİRIŞ}

Bibliyometrik yöntemler, literatür taramasına sistematik bir yaklaşım olarak günümüzde giderek daha popüler hale gelmektedir ( Siemieniako, 2018: 259). Bibliyometri, bilimsel iletişimin yapısını ve sürecini incelemek için güçlü yöntemler sunmaktadır (Borgman ve Furner, 1990: 4). Bibliyometri, özellikle farklı disiplinlerdeki literatürü değerlendirmek için büyük ölçüde nicel bir yöntem olarak kullanılmıştır (Osareh,1996:149). Bibliyometrik araştırmalarda belgelerin ya da yayınların belirli özellikleri incelenerek bilimsel iletişime ilişkin çeşitli veriler elde edilmektedir (A1, 2008: 19; Ulu ve Akdağ, 2015:5). Bu verilere bağlı olarak kişilerin, kurumların verimliliği ölçülebilmektedir (Ulu ve Akdağ, 2015:5).

Araştırmacıların farklı nedenlerle bibliyometrik araştırmalara yöneldiği bilinmektedir. Bibliyometrik araştırmalarla bir yandan herhangi bir konudaki en verimli araştırmacılar belirlenirken, diğer yandan da bunlar arasındaki etkileşimin boyutları gözler önüne serilebilmektedir (Al, 2008: 19). Bibliyometrik yöntemler kullanılarak disiplinler arası farklılıkların ortaya çıkarılabilmesi mümkün olduğu gibi, herhangi bir derginin daha yakından tanınması da sağlanabilmektedir (Yalçın, 2010: 210). Bununla beraber, bibliyometrik analiz, akademik kurumların bilimsel performansını ortaya koymak amacıyla da başvurulan bir yöntemdir (Zencir ve Kozak,2012:674). Bibliyometri, disiplinlerdeki ve disiplinler arasındaki bilgi yapılarını inceleyen bir araştırma alanıdır (Holden, Rosenberg ve Barker, 2005:1).

Bibliyometrik araştırmalar, benzer bir yaklaşımla çeşitli konularda ülkeler arasında, kurumlar arasında ya da ekoller arasında karşılaştırmalar yapılmasına da olanak sağlamaktadır (Al, 2008: 19). Süreli yayınların benzer amaçlarla incelenmeleri başka ülkelerde ve disiplinlerde yaygın olarak yapılmaktadır. Bu tür incelemelerin çoğunlukla akademik ve diğer kurumları bilimsel dergilere katkıları açısından değerlendirmektedir. Diğer bir inceleme ise, seçilmiş dergilerde yayımlanan makalelerin içeriklerini incelenerek ilgili disiplinin gelişimine ilişkin değerlendirmeler yapılmaktadır (Beıkman ve 
Kozan 1979: 9). Koehler (2001) bibliyometri ile uğraşan kişilerin en azından dört gruba ayrılabileceğini belirtmekte ve bu grupları (120);

- Atıf analizi üzerine çalışanlar,

- Ortak atıf (co-citation) analizi üzerine odaklananlar,

- Bireylerin, kurumların ve ülkelerin üretkenliğine ve etki analizine odaklananlar,

- Kitap, makale, patent ve diğer bilgi ürünleri ile ilgilenenler (Koehler, 2001:120)

Bir bilim dalının bir ülkedeki durumunu anlayabilmek ve değerlendirebilmek için en önemli analizlerden bir tanesi, o alanda yapılmış yayınların incelenmesidir. Dünya genelinde akademik nitelikli yayınlardaki gelişmelerin analiz edilmesi ile ilgili çalışmalar giderek yaygınlaşmaktadır. Gerek dünya genelinde gerekse bir ülkedeki, bir bilim dalıyla ilgili belirli zaman aralıklarında yapılacak "stok tesbiti" araştırmalarının yararlı sonuçları olduğu hususu, bilim adamları arasında genel kabul gören bir konudur. Bu yolla elde edilecek bilgi, bir yanda o bilim dalının zaman içerisinde gösterdiği gelişmeyi ve egemen eğilimleri anlama, bir yanda da var olan sorunları ortaya çıkarma ve bunları görebilmek için yapılabilecekleri tartışma olanağı sağlayabilmektedir (Üsdiken ve Pasadeos, 1993: 73; Kozak, 1994: 23 24). Bibliyometri, geçtiğimiz on y1lda bilim politikası ve araştırma yönetiminin standart bir aracı haline gelirken son yirmi yılda ise önemli bilim alanlarıyla ilgili birçok kapsamlı bibliyometrik çalışma yayınlanmıştır (Khiste ve Paithankar, 2017: 81; Avasthi, De ve Dikkatwar,2021:523).

Genellikle bibliyometrik çalışmaların turizm genelinde yoğunlaştığı görülmektedir (Yılmaz, 2017: 66). Marka alanı ile ilgili yayımlanmış bibliyometrik çalışmalar incelendiğinde ise bu alanda Marka (Öcel,2019), Marka Kişiliği (Radler, 2018; Khurana ve Kumar, 2019; Llanos-Herrera ve Merigo, 2019), Müşseri Sadakati ve Marka Yönetimi (Tartaglione, Cavacece, Russo ve Granata, 2019), Marka Kimliği, Marka Kişiliği, Marka İmajı ve Marka Konumlandırma (İnce ve Uygurtürk, 2019), Marka Deneyimi (Salam,2020), Müşteri Sadakati (Siemieniako, 2018; Dubina, Us, Pimonenko ve Lyulyov, 2020), Marka ve Ürün Silme (Zhu, Martins, Shah ve Sarkis, 2021), Marka Trendleri (Majerova, Gajanova ve Nadanyiova, 2021), Marka Değeri (Neme-Chaves ve Rodríguez-González, 2019), Lüks Marka Pazarlama (Aliyev, Taylan Urkmez ve Wagner, 2019), Kar Amacı Gütmeyen Markalama (Sepulcri, Mainardes ve Belchior, 2020), Tüketici marka ilişkileri (Fetscherin ve Heinrich,2014) çalışmalar yer almaktadır.

Bibliyometrik çalışmaların dikkat çeken yaygınlığına rağmen, ulusal ve uluslararası yazın incelendiğinde marka sadakati özelinde yapılmış herhangi bir bibliyometrik çalışmaya rastlanılmamıştır. Buradan hareketle bu araştırmanın amacı; Türkiye'de marka sadakati alanının daha yakından tanınması ve araştırmacılara bu alanın yapısı ile ilgili bilgilerin sunulmasıdır. Tüm bunların 1şı̆̆ında ulusal yazında bibliyometri çalışmalarının turizm ve turizm ile ilgili konular çerçevesinde yapıldığı göz önüne alındığında bu çalışmanın hem ilgili yazına katkı sağlayacağı hem de bu alanda çalışan araştırmacılara yol göstereceği düşünülmektedir. 


\section{KAVRAMSAL ÇERÇEVE}

Markalar, şirketlerin önemli maddi olmayan varlıklarından biri olarak önemli rol oynamaktadır. Tüketiciler ve şirketler arasında arayüz olmakta ve tüketiciler markalar aracılığıyla güven, bağlılık, ilgilenim ve sadakat geliştirebilir (Sivarajah ve Sritharan, 2014:1).

Sadakat kavramı, pazarlama alanındaki araştırmalar için en ilgi çekici konulardan biri olmaya devam etmektedir (Cătoiu, Gardan ve Geangu, 2012: 284). Benzer şekilde Marka sadakati konusu da pazar araştırmacıları, pazarlama yöneticileri ve pazarlama akademisyenleri tarafindan büyük ilgi görmektedir. Bu kavram, birçok pazarlama yöneticisi için de önemli bir konudur ve şirketler her yıl pazar araştırma organizasyonları aracılı̆̆ıyla marka sadakat seviyelerini takip etmek için milyonlarca dolar harcamaktadır. Pazar araştırması şirketlerinin birçoğuna göre, marka sadakati araştırmaları bu kavramın marka yönetimi için önemini yansıtan kilit bir iş alanı olarak görmektedir (Bennett ve RundleThiele, 2005:250).

Uzun yıllardır pazarlama alanında oldukça üzerinde durulan bir kavram olan marka sadakati, tüketicilerin bir markaya olan bağlılığının ölçüsünü ifade etmektedir. Bu kavramı, tüketicinin kullanmakta olduğu markanın ürün özellikleri ya da fiyatı gibi ürüne ilişkin bir takım özelliklerde değişiklik yapılması durumunda kullanmakta olduğu bu markayı değiştirip diğer markaya geçme ihtimalini yansıtmaktadır (Aaker, 1991: 44-45). Marka sadakati, müşterilerin bir ürün kategorisindeki diğer tüm rakip markalara kıyasla o markayı tutarlı bir şekilde tercih etmelerine neden olan bir markaya karşı olumlu bir tutumdur (Ferrel ve Hartline, 2011: 204) .

Jacoby'e göre (1971) Marka sadakati, altı gerekli koşulla sahip (a) bilinçli (yani rasgele olmayan), (b) davranışsal tepki (yani satın alma), (c) zamanla devam ettirilen, (d) bazı karar verme birimleriyle yürütülen (e) bir ya da daha fazla alternatif marka için bu tür bir marka dışında (f) (karar verme, değerlendirme) gibi bir takım psikolojik süreçlerinin bir fonksiyonu şeklinde tanımlanmıştır (s. 655; Jacoby ve Kyner, 1973: 2).

Oliver' a (1997:1999) göre sadakati, durumsal etkilere ve pazarlama çabalarına rağmen, gelecekte tercih edilen bir ürünü ve hizmeti sürekli olarak tekrar satın almak veya yeniden değerlendirmek için duyulan derinlemesine bağlılık olarak tanımlamıştır (s. 34).

İlk olarak 1940'larda ortaya çıkan sadakat kavramı, ilk günlerinde araştırmacılar tarafından tek boyutlu bir yapı olarak iki farklı bakış açısıyla (Rundle-Thıele, 2005:494): "marka tercihi” (Guest, 1944: 16) ve "pazar payı" (Cunningham, 1956:141) şeklinde ifade edilmiştir.

Pazarlama alanında çalışan araştırmacılar ve yöneticiler 1950’lere kadar sadakati tüketici davranışı olarak tanımlamışlardır. Bu nedenle tüketici sadakatini sadece tekrarlı satın almanın miktarı ve değerine göre ölçmüşlerdir (Lu Ting Pong ve Tang Pui Yee, 2001: 21). 
Marka sadakatinin kavramsallaştırılması ve ölçülmesinin evrimi üç aşamada sınıflandırılabilmektedir. İlk aşamada yer alan araştırmacılar davranışsal ya da tutumsal bakış açısıyla tek boyutlu; ikinci aşamada yer alanlar hem davranışsal hem de tutumsal bakış acısıyla iki boyutlu ya da karma yaklaşım; üçüncü aşamada yer alanlar ise bilişsel unsurları içeren çok boyutlu ölçüm şeklinde sinıflandırılabilmektedir (Sheth ve Park, 1974; Fournier ve Yao, 1997: 452; Odin, Odin ve Florence, 2001: 76; Lu Ting Pong ve Tang Pui Yee, 2001:21; Punniyamoorthy ve Raj, 2007:223; Boora ve Singh, 2011:153).

Oliver $(1999 ; 2010)$ çalışmasında bireylerin sadakate bilişsel, duygusal, çabasal ve davranışsal olmak üzere dört aşamadan geçerek ulaşabildiklerini belirtmektedir. Bu yapıda tüketicilerin ilk olarak bilişsel olarak sadık oldukları, sonrasında duygusal anlamda sadık hale geldikleri, üçüncü aşamada ise çabasal sadakat oluştuğu ve en son aşamada ise davranışsal sadakatin geliştiğini belirtilmektedir (s. 35; s. 433).

Marka sadakati, tüketicilerin rutin olarak bir marka satın almasını ve başka bir markaya geçmeye direnmesini sağlar. Dolayısıyla tüketiciler markaya sadık kaldıkça marka değeri artacaktır (Yoo, Donthu ve Lee, 2000:197). Sadık müşterilerin firmaya birçok fayda sağlaması nedeniyle marka sadakati oldukça önemlidir (Kabiraj ve Shanmugan, 2011: 87). Marka sadakati, uygun yönetilir ve değerlendirilirse, çeşitli yollarla değer sağlayacak potansiyele sahip stratejik bir varlığın temsil etmektedir (Aaker, 1991:50). Marka sadakati arttıkça markanın tüketicilerinin rakip markaların faaliyetlerinden etkilenmeleri de azalabilmektedir. Marka sadakati, markanın satışlarını doğrudan etkileyeceğinden markanın ileriki dönem karlılığını arttırması açısından marka denkliğinin temel belirleyicilerinden biri niteliğindedir (Aaker, 1991: 44-45). Marka sadakati rekabet avantajı sağlamada kritik öneme sahip olmasının yanında yüksek marka sadakati ise, genişleme, yüksek pazar payı, yüksek yatırım getirisi ve nihayetinde yüksek marka değerine katkıda bulunan bir varlıktır (Kabiraj ve Shanmugan, 2011: 85).

Literatürde pazarlama alanında çeşitli bibliyometrik analizlerin yapıldığı görülmektedir. Pazarlama ile ilgili yapılan bibliyometrik çalışmalarda marka ve marka sadakati kavramı önemli bir yer tutmaktadır. Bu doğrultuda pazarlama, marka ve marka sadakati çalışmalarının derinlemesine incelenmesi önem arz etmektedir. Bu nedenle incelenen literatür çalışmalarının sonuçları aşağıda ifade edilmektedir.

Bakır (2013) "pazarlama alanında yapılan doktora tezlerinin kategorik olarak değerlendirilmesi (1994 ile 2012 yılları arası)" isimli çalışmasında en fazla "pazarlama iletişimi" "tüketici davranışları" ve "marka ve marka yönetimi”" alanlarında çalışmaların yapıldığını tespit etmiştir.

Bozyiğit ve Yaşa (2013) "Pazarlama Konusunda Yapılan Lisansüstü Tezlere İlişkin Bir Araştırma" başlıklı makalelerinde 2000 yılı sonrası yapılan yüksek lisans ve doktora tezlerini incelemişlerdir. Yapılan inceleme sonucunda en fazla "tüketici davranışları", "reklam ve marka" ve "hizmet" alanlarında çalışmalar yapıldığı sonucuna ulaşmışlardır. 
Chabowski ve diğerlerinin (2013) uluslararası dergileri inceleyerek 120 uluslararası makaleye yaptıkları bibliyometrik analiz sonucunda marka alanında genel olarak uluslararası markalaşma stratejisi, marka konumlandırma, marka/ülke menşei, marka kavramı-imajı ve marka performansı konularının incelendiği sonucuna ulaşmışlardır.

Çatı ve Öcel (2018) Türkiye'de 2004-2016 yılları arasında pazarlama alanında yazılmış makalelerin bibliyometrik incelenmesi yapmışlardır. Araştırma sonuçlarına göre en çok çalışılan konular; "pazarlama yönetimi ve stratejisi", "pazarlama iletişimi", "sosyal pazarlama ve yeşil pazarlama" şeklindedir.

Barahona ve diğ. (2018) 2005 ve 2014 yılları arasında pazarlama dergisi ve pazarlama araştırmaları dergisinde toplamda 1169 özetin incelendiği araştırma sonuçlarına göre en fazla tüketici, ürün, müşteri, etki, marka, pazarlama ve firma kelimelerinin çok fazla kullanıldığını ortaya çıkarmışlardır.

Gürbüz ve Bozkurt'un (2018) 2008-2016 yılları arasında Pazarlama ve Pazarlama Araştırmaları Dergisinde yayınlanan 75 makaleyi bibliyometrik atıf analizi tekniği kullanılarak incelemiştir. Araştırma sonuçlarına göre en çok 'tüketici davranışı', 'marka' ve 'pazarlama araştırması' konularına ağırlık verildiği görülmüştür.

Gülmez, Yalçıntaş, Kurtulgan ve Özbay (2019) 1981-2018 yılları arasında Türkiye'de Pazarlama alanında yazılan Doktora tezlerini inceledikleri çalışmalarına göre pazarlama literatüründe en çok ele alınan konu başlıklarının sırasıyla e-pazarlama/dijital pazarlama, pazarlama iletişimi ve pazarlama stratejileri konu başl1kları olduğu sonucuna ulaşılmıştır.

Öcel'in (2019) 1995-2018 yılları arasında Türkiye'de marka alanında yazılmış doktora tezlerinin bibliyometrik analiz yöntemi ile incelediği çalışmasına göre marka alanında en fazla çalışılan konu; "marka değeri”, "markalama ve tüketici davranışları", "marka imajı", "marka sadakati” ve "marka iletişimi” konularında olduğu görülmektedir. Buna karşın en az çalışma konu ise "marka etiği”, "marka kültürü”, "markalama ve sosyal medya", "marka bağlılı̆̆ı", "marka deneyimi” ve "destinasyon markalaşması" konularında yapıldığı görülmektedir.

İnce ve Uygurtürk (2019) Marka Kimliği, Marka Kişiliği, Marka İmajı ve Marka Konumlandırma alanında yapılan lisansüstü tezleri inceledikleri çalışmalarına göre marka ile ilgili tez çalışmalarının 2006 yılından sonra artış göstermeye başladığı, incelenen tezlerin \%86'sının yüksek lisans tezi çalışması olduğu, en fazla Marmara Üniversitesi tarafından marka ile ilgili tez çalışması yapıldığı ve çalışmaların \%70'inin işletme anabilim dalı tarafından gerçekleştirildiği görülmüştür. Çalışmalarda veri toplama yöntemlerinden en fazla anket yönteminin kullanıldığı ve en fazla çalışmanın da gida sektöründeki markalar üzerine yapıldığı tespit edilmiştir. 
Khurana ve Kumar (2019), marka kişiliği kavramı ile yayımlanmış makalelerin bibliyometrik analiz yöntemi ile inceledikleri çalışmalarında marka kişiliği boyutlarını derleyerek özetlemişlerdir. En çok ifade edilen Marka kişiliği boyutları ile sofistike, heyecan verici ve samimiyet boyutlarıdır.

Tartaglione, Cavacece, Russo ve Granata (2019), 2000-2018 yılları arasında Müşteri sadakati ve marka yönetimi üzerine yayınlanmış 337 çalışmayı haritalama tekniği ve bibliyometrik analiz yöntemi ile inceledikleri çalışmalarına göre "müşteri memnuniyeti”, müşteri sadakati ve marka yönetimi üzerine yapılan çalışmalarda en sık kullanılan, alakalı ve atıfta bulunulan konu olup, bunu "tüketici güveni", "marka topluluğu”, “tüketici algıları", "tüketici davranışı” ve "rekabet avantajı” izlemektedir.

Siemieniako (2018), 2003-2017 yılları arasında işletmeden işletmeye bağlamda Müşteri sadakati alanında Scopus veritabanında yayınlanan bilimsel çalışmaların bibliyometrik analiz yöntemi ile incelediği çalışmasında müşteri sadakati alanında en çok kullanılan 23 anahtar kelime tespit edilmiştir.

\section{YÖNTEM}

Çalışmanın amacı, Türkiye'de Marka sadakati kavramı ile yazılan lisansüstü tezlerinin ve yayımlanan makalelerin bibliyometrik yöntemle incelenerek, marka sadakati kavramının gelişim durumunu anlayabilmek, değerlendirebilmek ve bu alanla ilgili araştırmacılara bilgiler sunmaktır. $\mathrm{Bu}$ araştırma YÖK Ulusal Tez Merkezi veri tabanında kayıtlı lisansüstü tezleri ve Türkiye Akademik Arşivi (Harman) veri tabanındaki makaleler dikkate alınarak yapılmıştır. YÖK Ulusal Tez Merkezi ve Türkiye Akademik Arşivi (Harman) veri tabanına kayıtlı tezlerin ve makalelerin başlığında "marka sadakati" ve "brand Loyalty" kelimesi anahtar kelime olarak seçilmiş olup, 2002-2020 yılları arasında 168 izinli lisansüstü tezi ve 141 makale bu şekilde incelemeye alınmıştır.

İncelenen lisansüstü tezleri ve makalelerin hangi yılda yayınlandığı, üniversitesi, anabilim dalı, dergi adı, dili, araştırma yöntemi, araştırma tekniği, örnekleme seçme yöntemi, örneklem grubu ve marka sadakati kavramı ile ilişkisi incelenen kavramlar veri olarak ele alınmış ve bibliyometrik analiz yöntemi ile incelenmiştir.

Bibliyometrik analiz, yazarların kendi yayınlanmış çalışmalarında atıfta bulundukları ve aldıkları alıntılar açısından yayın örüntülerini belgeleyen bir metodolojidir (Heberger ve diğerleri, 2010: 25). Bibliyometri kavramı, matematiksel ve istatistisel yöntemlerinin kitaplara ve diğer iletişim araçlarına uygulanması olarak tanımlamıştır (Pritchard, 1969:348). Osareh (1996) bibliyometrinin terim olarak yeni olmasına karşın, uygulama ve kullanımının 1890'lara kadar gittiğini ifade etmektedir (s.149). Bibliyometri, bibliyometrik matematiği, sosyal bilimleri kapsayan gerçek anlamda disiplinler arası bir araştırma alanıdır (Khiste ve Paithankar, 2017:81; Avasthi, De ve Dikkatwar, 2021:523). Başlangıçta, bibliyometrik çalışma, bir alanın büyümesini değerlendirmek ve ölçmek için basit bir istatistiksel sayma yöntemiyken artık günümüzde Bibliyometrik teknikler çeşitli bilimsel göstergelerin belirlenmesi, bilimsel çıktıların değerlendirilmesi, kütüphaneler için dergi seçimi, belirli bir alanın araştırma 
potansiyelini tahmin etme vb. gibi çeşitli amaçlarla kullanılmaktadır (Khiste ve Paithankar, 2017:81; Avasthi, De ve Dikkatwar,2021:523).

$\mathrm{Bu}$ çalışmada aşağıdaki araştırma sorularına cevap aranmaya çalışılımıştır.

- Soru-1: YÖK Ulusal Tez Merkezi ve Türkiye Akademik Arşivi (Harman) veri tabanına kayıtlı marka sadakati adı ile ilgili kaç adet Lisansüstü Tezleri (yüksek lisans ve doktora tezi) ve makale yayınlanmıştır?

- Soru-2: Lisansüstü tezlerin ve makalelerin yıllara göre dağılımı nasıldır?

- Soru-3: Lisansüstü tezlerin üniversitelere göre dağılımı nasıldır?

- Soru-4: Lisansüstü tezlerin anabilim dallarına göre dağılımı nasıldır?

- Soru-5: Makalelerin yayımlandığı dergilere göre dağılımı nasıldır?

- Soru-6: Lisansüstü tezler ve makaleler hangi dilde yayınlanmıştır?

- Soru-7: Lisansüstü tezlerde ve makalelerde kullanılan araştırma yöntemi nelerdir?

- Soru-8: Lisansüstü tezlerde ve makalelerde kullanılan araştırma tekniği nelerdir?

- Soru-9: Lisansüstü tezlerde ve makalelerde kullanılan örnekleme seçme yöntemi nelerdir?

- Soru-10: Lisansüstü tezlerde ve makalelerde örneklem grubu nasıldır?

- Soru-11: Lisansüstü tezlerde ve makalelerde marka sadakati kavramı ile ilişkisi incelenen kavramların dağılımı nasıldır?

\section{BULGULAR}

Marka sadakati alanında yapılan çalışmaların, turizm, sağlık, ekonomi, coğrafya, işletme ve diğer bazı sosyal bilimler dergilerinde, kongre bildirilerinde, kitap bölümlerinde ve tezlerde çok geniş bir alanda yer alması nedeniyle taranacak dergi sayı ve süresinde sınırlandırmaya gidilmiştir. Bu nedenle taramada, 18 yıllık zaman diliminde akademik dergilerde yayımlanan çalışmalar ve lisansüstü tezleri dikkate alınmıştır. 2002-2020 yılları arasında marka sadakati kavramı ile ilgili 23 doktora tezi, 145 yüksek lisans tezi ve 141 tane makale yayınlanmıştır.

\section{Lisansüstü Tezlerinin ve Makalelerin Yıllara Göre Dağılımı}

Tablo 1'de yıllara göre en çok makalenin yayınlandığı yıl 2020 (26) iken yüksek lisans tezlerinin en çok yayınlandığı yıl 2019 (47) ve doktora tezlerinin ise 2020 (4) yılıdır. Marka sadakati kavramı ile ilgili yapılan çalışmaların çoğunluğunun yıllara göre sırasıyla 2019 (\%22) ve 2020 (\%12) yıllarında yayınlandığı görülmektedir. Ayrıca marka sadakati kavramı ile ilgili yapılan çalışmaların yıllara göre sayılarında artış gözlemlenmiştir. 
Tablo 1. Lisansüstü Tezlerinin ve Makalelerin Yıllara Göre Dağılımı

\begin{tabular}{ccccccccc}
\hline Yıl & \multicolumn{2}{c}{ Yüksek Lisans Tezi } & \multicolumn{2}{c}{ Doktora Tezi } & \multicolumn{2}{c}{ Makale } & \multicolumn{2}{c}{ Toplam } \\
\hline & $\mathrm{n}$ & $\%$ & $\mathrm{n}$ & $\%$ & $\mathrm{n}$ & $\%$ & $\mathrm{n}$ & $\%$ \\
2002 & 1 & 0,6 & 0 & 0 & 0 & 0 & 1 & 0,3 \\
2003 & 2 & 1,3 & 0 & 0 & 0 & 0 & 2 & 0,6 \\
2005 & 1 & 0,6 & 1 & 4,3 & 0 & 0 & 1 & 0,3 \\
2006 & 0 & 0 & 0 & 0 & 1 & 0,7 & 1 & 0,3 \\
2007 & 5 & 3,4 & 0 & 0 & 1 & 0,7 & 6 & 1,9 \\
2008 & 1 & 2 & 0 & 0 & 0 & 0 & 3 & 0,9 \\
2009 & 5 & 0,6 & 0 & 0 & 1 & 0,7 & 2 & 0,6 \\
2010 & 6 & 4,4 & 2 & 8,6 & 4 & 2,8 & 11 & 3,5 \\
2011 & 4 & 2,7 & 2 & 8,6 & 4 & 2,8 & 10 & 4,5 \\
2012 & 3 & 2 & 3 & 13 & 5 & 3,5 & 13 & 4,2 \\
2013 & 4 & 2,7 & 1 & 4,3 & 6 & 4,2 & 11 & 3,5 \\
2014 & 5 & 3,4 & 3 & 13 & 7 & 4,9 & 15 & 4,8 \\
2015 & 14 & 9,6 & 3 & 13 & 11 & 7,8 & 28 & 9 \\
2016 & 10 & 6,8 & 2 & 8,6 & 15 & 10 & 27 & 8,7 \\
2017 & 10 & 6,8 & 0 & 0 & 18 & 12 & 28 & 9 \\
2018 & 15 & 10,3 & 1 & 4,3 & 14 & 9,9 & 30 & 9,7 \\
2019 & 47 & 32,4 & 2 & 8,6 & 20 & 14 & 69 & 22 \\
2020 & 9 & 6,2 & 4 & 17 & 26 & 18 & 39 & 12 \\
Toplam & 145 & 100 & 23 & 100 & 141 & 100 & 309 & 100 \\
\hline
\end{tabular}

\section{Lisansüstü Tezlerinin ve Makalelerin Yayın Diline Göre Dağılımı}

Grafik 1. Lisansüstü Tezlerinin ve Makalelerin Yayın Diline Göre Dağılımı

Lisansüstü Tezlerin ve Makalelerin Yabancı Dil Türüne Göre Sayısı

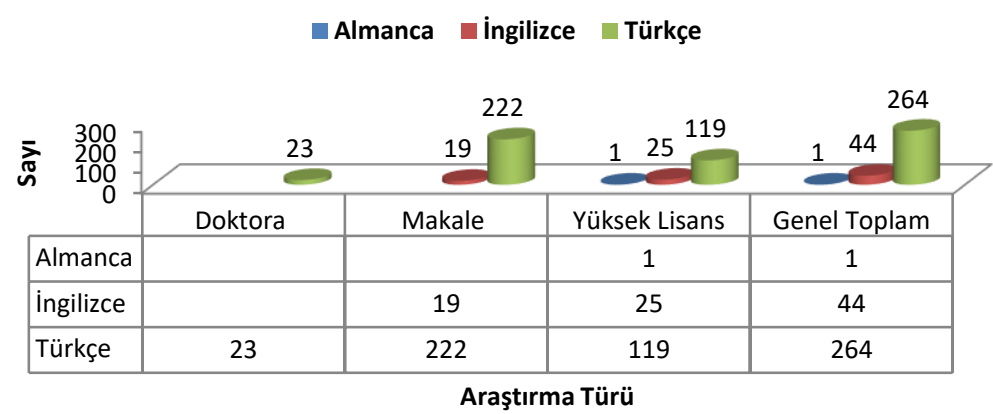

Marka sadakati kavramı ile ilgili yayınlanmış lisansüstü tezleri ve makaleleri incelediğimizde en az çalışma Almanca (1) sonra sırasıyla İngilizce (44) ve Türkçe (264) dillerinde yayınlanmıştır. Grafik 1 'de çalışmaların türüne göre Almanca, İngilizce ve Türkçe dillerinde yayınlandıkları görülmektedir. İngilizce dilinde 19 makale, 25 yüksek lisans tezi yayınlanırken doktora tezi yayınlanmamıştır. Türkçe dilinde 23 doktora tezi, 119 yüksek lisans tezi ve 222 makale yayınlanmıştır. 


\section{Lisansüstü Tezlerin Üniversitelere Göre Dağılımı}

Tablo 2. Lisansüstü Tezlerin Üniversitelere Göre Dağılımı

\begin{tabular}{|c|c|c|c|c|c|c|c|c|c|c|c|}
\hline & Doktora & Yüksek Li & & & Toplam & & Doktora & Yüksek L & & & Toplam \\
\hline & Türkçe & Almanca & İngilizce & Türkçe & & & Türkçe & Almanca & İngilizce & Türkçe & \\
\hline Ankara Yıldırım Beyazıt Üni. & & & & 1 & 1 & Giresun Üni. & & & & 1 & 1 \\
\hline Manisa Celal Bayar Üni. & & & & 1 & 1 & $\begin{array}{l}\text { Gümüşhane } \\
\text { Üni. }\end{array}$ & & & & 2 & 2 \\
\hline Niğde Ömer Halisdemir Üni. & & & & 1 & 1 & $\begin{array}{l}\text { Hasan } \\
\text { Kalyoncu Üni. }\end{array}$ & 2 & & & & 2 \\
\hline Abant İzzet Baysal Üni. & & & & 3 & 3 & $\begin{array}{l}\text { İstanbul Arel } \\
\text { Üni. }\end{array}$ & & & & 1 & 1 \\
\hline Afyon Karahisar Üni. & & & & 1 & 1 & $\begin{array}{l}\text { İstanbul Aydın } \\
\text { Üni. }\end{array}$ & & & 1 & 2 & 3 \\
\hline Ağrı İbrahim Çeçen Üni. & 1 & & & 1 & 1 & $\begin{array}{l}\text { İstanbul Bilgi } \\
\text { Üni. }\end{array}$ & & & 3 & & 3 \\
\hline Akdeniz Üni. & 1 & & & & 1 & $\begin{array}{l}\text { İstanbul } \\
\text { Teknik Üni. }\end{array}$ & & & & 1 & 1 \\
\hline Anadolu Üni. & & & & 3 & 3 & $\begin{array}{l}\text { İstanbul } \\
\text { Ticaret Üni. }\end{array}$ & & & & 3 & 3 \\
\hline Ankara Hacı Bayram Veli Üni. & & & & 1 & 1 & İstanbul Üni. & 4 & & & 4 & 8 \\
\hline Ankara Üni. & 1 & & & 3 & 4 & $\begin{array}{l}\text { Karadeniz } \\
\text { Teknik Üni. }\end{array}$ & & & & 2 & 2 \\
\hline Atatürk Üni. & & & & 1 & 1 & Kırıkkale Üni. & 1 & & & & 1 \\
\hline Atılım Üni. & & & 1 & & 1 & Kocaeli Üni. & 1 & & & 1 & 2 \\
\hline Bahçeşehir Üni. & & & 8 & 7 & 15 & $\begin{array}{l}\text { Kto Karatay } \\
\text { Üni. }\end{array}$ & & & & 1 & 1 \\
\hline Balıkesir Üni. & & & & 5 & 5 & Maltepe Üni. & & & & 1 & 1 \\
\hline Bartın Üni. & & & & 1 & 1 & Marmara Üni. & 5 & 1 & 7 & 18 & 31 \\
\hline Başkent Üni. & & & & 1 & 1 & Nişantaşı Üni. & & & & 1 & 1 \\
\hline Beykent Üni. & 1 & & & 5 & 6 & $\begin{array}{l}\text { Pamukkale } \\
\text { Üni. }\end{array}$ & & & & 1 & 1 \\
\hline Bozok Üni. & & & & 1 & 1 & $\begin{array}{l}\text { Recep Tayyip } \\
\text { Erdoğan Üni. }\end{array}$ & & & & 1 & 1 \\
\hline Bülent Ecevit Üni. & & & & 1 & 1 & $\begin{array}{l}\text { Sakarya } \\
\text { Uygulamalı } \\
\text { Bilimler Üni. }\end{array}$ & & & & 1 & 1 \\
\hline Çankırı Karatekin Üni. & & & & 1 & 1 & Sakarya Üni. & & & & 2 & 2 \\
\hline Çukurova Üni. & & & & 1 & 1 & Selçuk Üni. & & & & 3 & 3 \\
\hline Deniz Harp Okulu & & & & 1 & 2 & $\begin{array}{l}\text { Süleyman } \\
\text { Demirel Üni. }\end{array}$ & & & & 1 & 1 \\
\hline Dokuz Eylül Üni. & & & 1 & 1 & 2 & Toros Üni. & & & & 1 & 1 \\
\hline Dumlupınar Üni. & & & & 1 & 1 & Trakya Üni. & 2 & & & 1 & 3 \\
\hline Düzce Üni. & & & & 3 & 3 & $\begin{array}{l}\text { Türk Hava } \\
\text { Kurumu Üni. }\end{array}$ & & & & 2 & 2 \\
\hline
\end{tabular}




\begin{tabular}{|c|c|c|c|c|c|c|c|c|c|}
\hline Ege Üni. & & 3 & 3 & Ufuk Üni. & & & & 3 & 3 \\
\hline Erciyes Üni. & & 3 & 3 & Uşak Üni. & & & & 1 & 1 \\
\hline Eskişehir Osmangazi Üni. & & 2 & 2 & Yaşar Üni & & & & 1 & 1 \\
\hline Galatasaray Üni. & & 4 & 4 & Yedi Tepe Üni. & & & 4 & & 4 \\
\hline Gazi Üni. & 2 & 3 & 5 & $\begin{array}{l}\text { Yıldız Teknik } \\
\text { Üni. }\end{array}$ & & & & 2 & 2 \\
\hline Gebze Yüksek Teknoloji Ens. & 2 & & 2 & $\begin{array}{l}\text { Yüzüncü Yıll } \\
\text { Üni. }\end{array}$ & & & & 1 & 1 \\
\hline Giresun Üni. & & 1 & 1 & Genel Toplam & 23 & 1 & 25 & 119 & 168 \\
\hline
\end{tabular}

Tablo 2 incelendiğinde yayınlanan doktora ve yüksek lisans tezleri içerisinde yayının en fazla olduğu Üniversiteler olarak sırasıyla; Marmara Üniversitesi (31), Bahçeşehir Üniversitesi (15), İstanbul Üniversitesi (8), Beykent Üniversitesi (6) ve Gazi Üniversitesi (5) olduğu görülmektedir.

\section{Lisansüstü Tezlerin Anabilim Dalına Göre Dağılımı}

Aşağıda Tablo 3'te doktora ve yüksek lisans tezlerinin anabilim dallarına göre dağılımı ile ilgili açıklayıcı istatistikler verilmektedir. Tezlerinin içerisinde en fazla sırasıyla "İşletme Anabilim Dalı" (100), "Halkla İlişkiler Anabilim”(8), "İşletme Yönetimi Ana bilim dalı" (7), "Halkla İlişkiler ve Tanıtım Anabilim Dalı" (6) ve "Turizm İşletmeciliği Anabilim Dalından” (3) çıktığı görülmektedir. Tablo 3 incelendiğinde işletme anabilim dalının dışında da diğer anabilim dallarının marka sadakati konusu ile ilgilendiği görülmektedir.

Tablo 3. Lisansüstü Tezlerin Anabilim Dalına Göre Dağılımı

\begin{tabular}{|c|c|c|c|c|c|c|c|c|c|c|c|}
\hline & \multirow{2}{*}{ 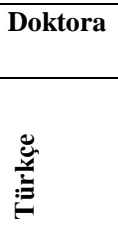 } & \multicolumn{3}{|c|}{ Yüksek Lisans } & \multirow[b]{2}{*}{ 音 } & & \multirow{2}{*}{ 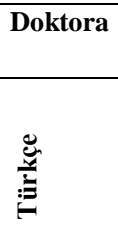 } & \multicolumn{3}{|c|}{ Yüksek Lisans } & \multirow[b]{2}{*}{$\frac{\Xi}{\stackrel{a}{a}}$} \\
\hline & & 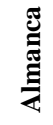 & . & 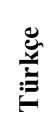 & & & & 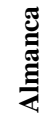 & 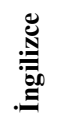 & $\underset{\Xi}{\stackrel{\Xi}{\Xi}}$ & \\
\hline $\begin{array}{l}\text { İşletme Mühendisliği } \\
\text { ABD }\end{array}$ & & & & 1 & 1 & İşletme (Almanca) ABD & & 1 & & & 1 \\
\hline $\begin{array}{l}\text { Lisansüstü Eğitim } \\
\text { Enstitüsü }\end{array}$ & & & & 1 & 1 & İşletme (İngilizce) ABD & & & 8 & & 8 \\
\hline Reklamcılık ABD & & & & 1 & 1 & İşletme ABD & 15 & & 9 & 76 & 100 \\
\hline Sosyal Bilimler ABD & & & 1 & & 1 & İşletme Bilim Dalı & & & 1 & 3 & 4 \\
\hline $\begin{array}{l}\text { Turizm İşletmeciliği } \\
\text { ABD }\end{array}$ & & & & 3 & 3 & İşletme Yönetimi ABD & & & $\mathbf{1}$ & 6 & 7 \\
\hline $\begin{array}{l}\text { Beden Eğitimi Ve Spor } \\
\text { ABD }\end{array}$ & 1 & & & 1 & 2 & $\begin{array}{l}\text { Küresel Pazarlama Ve } \\
\text { Marka Yönetimi ABD }\end{array}$ & & & & 1 & 1 \\
\hline $\begin{array}{l}\text { Deniz Lojistik Yönetimi } \\
\text { ABD }\end{array}$ & & & & 2 & 2 & $\begin{array}{l}\text { Uluslararası Ticaret Ve } \\
\text { Pazarlama ABD }\end{array}$ & & & & 1 & 1 \\
\hline $\begin{array}{l}\text { Endüstri Mühendisliği } \\
\text { ABD }\end{array}$ & & & 1 & & 1 & Pazarlama ABD & & & 1 & & 1 \\
\hline
\end{tabular}




\begin{tabular}{|c|c|c|c|c|c|c|c|c|c|}
\hline Genel İşletme Bilim Dalı & & 1 & 1 & Pazarlama Bilim Dalı & 1 & & 1 & & 2 \\
\hline $\begin{array}{l}\text { Girişimcilik Ve İnovasyon } \\
\text { Yönetimi ABD }\end{array}$ & 1 & & 1 & Pazarlama İletişimi ABD & & & & 1 & 1 \\
\hline $\begin{array}{l}\text { Giyim Endüstrisi Ve } \\
\text { Giyim Sanatları ABD }\end{array}$ & & 1 & 1 & $\begin{array}{l}\text { Reklam Ve Stratejik Marka } \\
\text { İetişimi Bilim Dalı }\end{array}$ & & & & 1 & 1 \\
\hline Halkla İlişkiler ABD & & 8 & 8 & $\begin{array}{l}\text { Sağlık Kurumları } \\
\text { İşletmeciliği ABD }\end{array}$ & 1 & & & & 1 \\
\hline $\begin{array}{l}\text { Halkla İlişkiler Ve } \\
\text { Reklamcıllk ABD }\end{array}$ & & 1 & 1 & Sosyal Bilimler Enstitüsü & & & 1 & 1 & 2 \\
\hline $\begin{array}{l}\text { Halkla İlişskiler Ve } \\
\text { Tanıtım ABD }\end{array}$ & 4 & 2 & 6 & Spor Bilimleri ABD & 1 & & & & 1 \\
\hline İletişim ABD & & 1 & 1 & $\begin{array}{l}\text { Spor Yönetim Bilimleri } \\
\text { ABD }\end{array}$ & & & & 1 & 1 \\
\hline İstatistik ABD & & 1 & 1 & $\begin{array}{l}\text { Turizm İşletmeciliği } \\
\text { Eğitimi ABD }\end{array}$ & & & & 1 & 1 \\
\hline & & & & Genel Toplam & 23 & 1 & 25 & $\begin{array}{l}11 \\
9\end{array}$ & 168 \\
\hline
\end{tabular}

\section{Makalelerin Yayınlanan Dergiye Göre Dağılımı}

Tablo 4. Makalelerin Yayınlanan Dergiye Göre Dağılımı

\begin{tabular}{|c|c|c|c|c|c|c|c|}
\hline Dergi Adı & İngilizce & Türkçe & $\begin{array}{l}\text { Genel } \\
\text { Toplam }\end{array}$ & Dergi Adı & İngilizce & Türkçe & $\begin{array}{l}\text { Genel } \\
\text { Toplam }\end{array}$ \\
\hline $\begin{array}{l}\text { Ankara Üni. Siyasal Bilgiler Fakültesi } \\
\text { Dergisi }\end{array}$ & & 1 & 1 & Journal of Naval Science and Engineering & 1 & & 1 \\
\hline $\begin{array}{l}\text { Atatürk Üni. İktisadi ve İdari Bilimler } \\
\text { Dergisi }\end{array}$ & & 1 & 1 & $\begin{array}{l}\text { Journal Of Tourism And Gastronomy } \\
\text { Studies }\end{array}$ & & 3 & 3 \\
\hline 19 Mayıs Sosyal Bilimler Dergisi & & 1 & 1 & Journal of Yasar University & 2 & 1 & 3 \\
\hline $\begin{array}{l}\text { Akademik Araştırmalar ve Çalış̧malar } \\
\text { Dergisi }\end{array}$ & & 1 & 1 & Kafkas Üni. İiBF Dergisi & & 1 & 1 \\
\hline Akademik Sosyal Araştırmalar Dergisi & & 1 & 1 & Kırklareli Üni. İ̈BF Dergisi & & 1 & 1 \\
\hline Akdeniz Üni. İletişim Fakültesi Dergisi & & 1 & 1 & Kocaeli Üni. Sosyal Bilimler Dergisi & & 1 & 1 \\
\hline $\begin{array}{l}\text { Al-Farabi International Journal on Social } \\
\text { Sciences }\end{array}$ & & 1 & 1 & $\begin{array}{l}\text { Küresel İktisat ve İşletme Çalış̧maları } \\
\text { Dergisi }\end{array}$ & & 1 & 1 \\
\hline Anadolu Üni. Sosyal Bilimler Dergisi & & 1 & 1 & Maltepe Üni. İletişim Fakültesi Dergisi & & 1 & 1 \\
\hline $\begin{array}{l}\text { Atatürk Üni. İktisadi ve İdari Bilimler } \\
\text { Dergisi }\end{array}$ & & 2 & 2 & MANAS Sosyal Araştırmalar Dergisi & & 1 & 1 \\
\hline Atatürk Üni. Sosyal Bilimler Ens. Dergisi & & 2 & 2 & $\begin{array}{l}\text { Manisa Celal Bayar Üni. Sosyal Bilimler } \\
\text { Dergisi }\end{array}$ & & 1 & 1 \\
\hline Beykent Üni. Sosyal Bilimler Dergisi & & 3 & 3 & Marmara Üni. Öneri Dergisi & & 4 & 4 \\
\hline Bingöl Üni. İ̈BF Dergisi & & 1 & 1 & Marmara Üni. İ̈B Dergisi & 1 & 2 & 3 \\
\hline Bingöl Üni Sosyal Bilimler Ens. Dergisi & 1 & 2 & 3 & $\begin{array}{l}\text { Niğde Üni. Beden Eğitimi Ve Spor } \\
\text { Bilimleri Dergisi }\end{array}$ & 1 & & 1 \\
\hline
\end{tabular}




\begin{tabular}{|c|c|c|c|c|c|c|c|}
\hline $\begin{array}{l}\text { Business \& Management Studies: An } \\
\text { International Journal }\end{array}$ & 1 & 1 & 2 & ODTÜ Gelişme Dergisi & & 1 & 1 \\
\hline Business and Economics Research Journal & & 1 & 1 & $\begin{array}{l}\text { Online Academic Journal of Information } \\
\text { Technology }\end{array}$ & & 1 & 1 \\
\hline $\begin{array}{l}\text { CBÜ Beden Eğitimi ve Spor Bilimleri } \\
\text { Dergisi }\end{array}$ & & 1 & 1 & Ömer Halisdemir Üni. İïBF Dergisi & 2 & 2 & 4 \\
\hline $\begin{array}{l}\text { 44Celal Bayar Üniversitesi Sosyal Bilimler } \\
\text { Dergisi }\end{array}$ & & 2 & 2 & $\begin{array}{l}\text { Pazarlama ve Pazarlama Araştırmaları } \\
\text { Dergisi }\end{array}$ & & 1 & 1 \\
\hline Çukurova Araştırmaları Dergisi & & 1 & 1 & PressAcademia Procedia & 1 & & 1 \\
\hline Çukurova Üni. Sosyal Bilimler Ens. Dergisi & & 1 & 1 & $\begin{array}{l}\text { Research Journal of Business and } \\
\text { Management }\end{array}$ & & 1 & 1 \\
\hline $\begin{array}{l}\text { Dokuz Eylül Üni. Sosyal Bilimler Ens. } \\
\text { Dergisi }\end{array}$ & & 1 & 1 & $\begin{array}{l}\text { Selçuk Üni. Beden Eğitimi ve Spor Bilim } \\
\text { Dergisi }\end{array}$ & & 1 & 1 \\
\hline Dumlupınar Üni. Sosyal Bilimler Dergisi & & 1 & 1 & Seyahat ve Otel İşletmeciliği Dergisi & & 2 & 2 \\
\hline Düzce Üni. Sosyal Bilimler Ens. Dergisi & & 1 & 1 & Social Sciences (NWSASOS) & & 1 & 1 \\
\hline Erciyes İletişim Dergisi & 1 & & 1 & $\begin{array}{l}\text { Sivas Cumhuriyet Üni. İktisadi ve İdari } \\
\text { Bilimler Dergisi }\end{array}$ & & 1 & 1 \\
\hline Econharran Harran Üniversitesi İ̈BF Dergisi & & 1 & 1 & $\begin{array}{l}\text { Sosyal ve Beşeri Bilimler Araştırmaları } \\
\text { Dergisi }\end{array}$ & & 1 & 1 \\
\hline Ege Akademik Bakış & & 2 & 2 & Süleyman Demirel Üni. İİBF Dergisi & & 5 & 5 \\
\hline E-Journal of Intermedia & 1 & & 1 & Süleyman Demirel Üni. Vizyoner Dergisi & 1 & & 1 \\
\hline Ekonomik ve Sosyal Araştırmalar Dergisi & & 1 & 1 & Tekstil Ve Konfeksiyon & 1 & & 1 \\
\hline Electronic Journal of Vocational Colleges & & 3 & 3 & $\begin{array}{l}\text { The International New Issues In SOcial } \\
\text { Sciences }\end{array}$ & 1 & & 1 \\
\hline Elektronik Sosyal Bilimler Dergisi & & 2 & 2 & Tourism and Recreation & & 1 & 1 \\
\hline Galatasaray Üni. İletişim Dergisi & & 1 & 1 & Turizm Akademik Dergisi & & 2 & 2 \\
\hline Gazi Üni. İIBF Dergisi & & 1 & 1 & Turkish Journal of Marketing & 1 & 1 & 2 \\
\hline Gazi Üni. Sosyal Bilimler Dergisi & & 2 & 2 & Turkish Studies - Social & & 1 & 1 \\
\hline $\begin{array}{l}\text { Gaziantep University Journal of Social } \\
\text { Sciences }\end{array}$ & & 1 & 1 & Turkish Studies Social Sciences & & 1 & 1 \\
\hline Global Media Journal TR Edition & & 1 & 1 & Tüketici ve Tüketim Araştırmaları Dergisi & & 1 & 1 \\
\hline Zonguldak Karaelmas Üni. & & 1 & 1 & Türk Turizm Araştırmaları Dergisi & & 1 & 1 \\
\hline Sosyal Bilimler Dergisi & & & & & & & \\
\hline $\begin{array}{l}\text { Gümüşhane Üni. İletişim Fakültesi } \\
\text { Elektronik Dergisi }\end{array}$ & & 1 & 1 & Türkiye İletişim Araştırmaları Dergisi & & 1 & 1 \\
\hline Gümüşhane Üni. Sosyal Bilimler Ens. & 1 & 1 & 2 & Uludağ Üni. İiBF & 1 & 1 & 2 \\
\hline & & & & Dergisi & & & \\
\hline H.Ü. İİBF Dergisi & & 2 & 2 & $\begin{array}{l}\text { Uluslararası Hakemli Ekonomi Yönetimi } \\
\text { Araştırmaları Dergisi }\end{array}$ & & 1 & 1 \\
\hline $\begin{array}{l}\text { International Review of Economics and } \\
\text { Management }\end{array}$ & 1 & & 1 & $\begin{array}{l}\text { Uluslararası Halkla İlişkiler ve Reklam } \\
\text { Çalışmaları Dergisi }\end{array}$ & & 2 & 2 \\
\hline ileti-ş-im & & 1 & 1 & $\begin{array}{l}\text { Uluslararası İktisadi ve İdari İncelemeler } \\
\text { Dergisi }\end{array}$ & & 3 & 3 \\
\hline İletişim Araştırmaları & & 1 & 1 & $\begin{array}{l}\text { Uluslararası Sağlık Yönetimi Ve Stratejileri } \\
\text { Araştırma Dergisi }\end{array}$ & & 1 & 1 \\
\hline İNiF E - Dergi & & 1 & 1 & Uluslararası Toplum Araştırmaları Dergisi & & 2 & 2 \\
\hline
\end{tabular}




\begin{tabular}{|c|c|c|c|c|c|c|c|}
\hline $\begin{array}{l}\text { İnsan ve Toplum Bilimleri Araştırmaları } \\
\text { Dergisi }\end{array}$ & 1 & & 1 & $\begin{array}{l}\text { Uluslararası Turizm, İşletme, Ekonomi } \\
\text { Dergisi }\end{array}$ & & 1 & 1 \\
\hline İstanbul Aydın Üni. Dergisi & & 1 & 1 & $\begin{array}{l}\text { Uluslararası Yönetim İktisat ve İşletme } \\
\text { Dergisi }\end{array}$ & & 1 & 1 \\
\hline İstanbul Üni. İşletme Fakültesi Dergisi & & 2 & 2 & Uşak Üni. Sosyal Bilimler Dergisi & & 1 & 1 \\
\hline İşletme Araştırmaları Dergisi & & 6 & 6 & Yıldız Sosyal Bilimler Ens. Dergisi & & 1 & 1 \\
\hline İzmir İktisat Dergisi & 1 & 1 & 2 & $\begin{array}{l}\text { Yönetim, Ekonomi, Edebiyat,İslami ve } \\
\text { Politik Bilimler Dergisi }\end{array}$ & & 1 & 1 \\
\hline $\begin{array}{l}\text { Journal of Management Marketing and } \\
\text { Logistics }\end{array}$ & & 2 & 2 & ZKÜ Sosyal Bilimler Dergisi & & 1 & 1 \\
\hline & & & & Genel Toplam & 19 & 122 & 141 \\
\hline
\end{tabular}

Tablo 4 incelendiğinde marka sadakati kavramı ile ilgili yayınlanmış makaleler içerisinde en fazla sırasıyla "İşletme Araştırmaları Dergisi “(6), "Süleyman Demirel Üni. İ̈BF Dergisi” (5), "Marmara Üni. Öneri Dergisi” (4) de yayınlandığı görülmektedir. En fazla İngilizce makalenin yayınlandığı dergiler ise "Journal of Yasar University" (2) ve "Ömer Halisdemir Üni. İ̈BF Dergisi" (2) dir.

\section{Lisansüstü Tezlerinin ve Makalelerin Araştırma Yöntemine Göre Dağılımı}

Grafik 2. Lisansüstü Tezlerinin ve Makalelerin Araştırma Yöntemine Göre Dağılımı

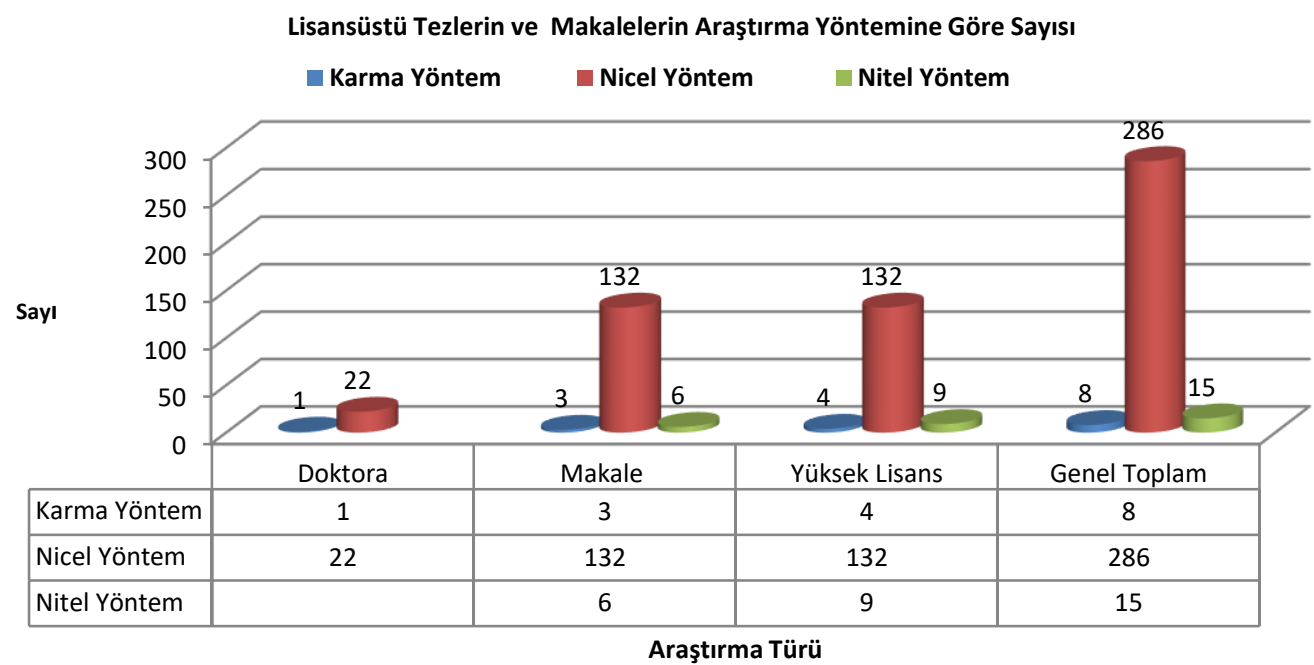

Yukarıda Grafik 2'de lisansüstü tezlerinin ve makalelerin tezlerinin araştırma yöntemine göre dağılımı ile ilgili açıklayıcı istatistiklere yer verilmiştir. Elde edilen bulgular incelendiğinde Sorucevaplandırılmış olacaktır.

"Soru-: Lisansüstü tezlerde ve makalelerde kullanılan araştırma yöntemi nelerdir?

Grafik 2 incelendiğinde lisansüstü tezlerinin ve makalelerin büyük çoğunluğunda Nicel araştırma yönteminin kullandığı görülmektedir. Buna karşın daha az sayıda Nitel araştırma yöntemi ve karma yöntem kullanılmıştır. 


\section{Lisansüstü Tezlerinin ve Makalelerin Veri Toplama Yöntemine Göre Dağılımı}

Aşağıda tablo 5'te Lisansüstü Tezlerinin ve Makalelerin veri toplama yöntemine göre dağılımını incelediğimizde en çok kullanılan veri toplam yöntemi anket tekniği olduğu görülmektedir. Diğer kullanılan veri toplama yöntemi ise görüşme ve odak grup görüşme yöntemidir.

Tablo 5. Lisansüstü Tezlerinin ve Makalelerin Veri Toplama Yöntemine Göre Dağılımı

\begin{tabular}{|c|c|c|c|c|}
\hline Veri Toplama Yöntemi & Doktora & Makale & Yüksek Lisans & Genel Toplam \\
\hline Anket Tekniği & 22 & 132 & 132 & 286 \\
\hline Anket Tekniği+Görüşme & 1 & 1 & 4 & 6 \\
\hline Anket+Odak Grup Görüşme & & 2 & & 2 \\
\hline Görüşme & & 1 & 5 & 6 \\
\hline Kavramsal & & 4 & 3 & 7 \\
\hline Odak Grup Görüşme & & 1 & 1 & 2 \\
\hline Genel Toplam & 23 & 141 & 145 & 309 \\
\hline
\end{tabular}

\section{Lisansüstü Tezlerinin ve Makalelerin Örnekleme Seçme Yöntemine Göre Dağılımı}

Aşağıda tablo 6'yı incelediğimizde çalışmaların büyük çoğunluğunda kolayda örnekleme seçme yönteminin kullanıldığı görülmektedir. Çalışmaların büyük bir kısmında örnekleme seçme yöntemi belirtilmediği görülmektedir.

Tablo 6. Lisansüstü Tezlerinin ve Makalelerin Örnekleme Seçme Yöntemine Göre Dağılımı

\begin{tabular}{|c|c|c|c|c|}
\hline Örnekleme Seçme Yöntemi & Doktora & Makale & Yüksek Lisans & Genel Toplam \\
\hline Basit Tesadüfi Örnekleme & & 14 & 17 & 31 \\
\hline Belirtilmemiş & 6 & 27 & 41 & 74 \\
\hline Kartopu Örnekleme & & 4 & 3 & 7 \\
\hline Kartopu Örnekleme+Kolayda Örnekleme & & & 2 & 2 \\
\hline Kolayda Örnekleme & 12 & 75 & 74 & 161 \\
\hline Kota Örnekleme & 1 & 3 & 2 & 6 \\
\hline Kota Örnekleme+Kolayda Örnekleme & & 1 & & 1 \\
\hline Küme Örnekleme & & 4 & 2 & 6 \\
\hline Yargisal/Amaçlı Örnekleme & 1 & 7 & 3 & 11 \\
\hline Yargısal/Amaçlı Örnekleme+Kartopu Örnekleme & & 2 & & 2 \\
\hline Yargisal/Amaçlı Örnekleme+Kota Örnekleme & & 1 & & 1 \\
\hline
\end{tabular}




\begin{tabular}{lcccc}
\hline Zümrelere/Katmanlı/Tabakalı Örnekleme & 2 & 1 & 1 & 4 \\
Zümrelere/Katmanlı/Tabakalı+Kolayda Örnekleme & 1 & 1 & & 2 \\
Zümrelere/Katmanlı/Tabakalı+Kota Örnekleme & & 1 & 145 & 309 \\
Genel Toplam & 23 & 141 & 145 \\
\hline
\end{tabular}

\section{Lisansüstü Tezlerinin ve Makalelerin Örneklem Grubuna Göre Dağılımı}

Aşağıda tablo 7'de lisansüstü tezlerinin ve makalelerin örneklem grubuna göre dağılımı ile ilgili açıklayıcı istatistikler verilmektedir. Bu bulgulara göre çalışmalarda en fazla yer verilen örneklem grubu tüketiciler sonra sırasıyla öğrenciler ve yöneticilerdir. Marka sadakati kavramı ile ilgili yayınlanan çalışmalarda farklı örneklem gruplarına yer verildiği görülmektedir.

Tablo 7. Lisansüstü Tezlerinin ve Makalelerin Örneklem Grubuna Göre Dağılımı

\begin{tabular}{ll}
\hline Örneklem Grubu & Çalışma Sayısı \\
\hline Akademik Personel & 2 \\
Alışveriş Siteleri & 1 \\
Hastalar & 1 \\
Kurum Çalışanları & 1 \\
Öğrenciler & 61 \\
Öğretmenler & 2 \\
Taksiciler & 1 \\
Taraftar & 2 \\
Tüketiciler & 223 \\
Veliler & 1 \\
Yerel Halk & 1 \\
Yöneticiler & 6 \\
Genel Toplam & 282 \\
\hline
\end{tabular}

\section{Lisansüstü Tezler ve Makalelerde Marka Sadakati Kavramı İle İlişkisi İncelenen Kavramların Dağılımı}

Aşağıda tablo 8'de marka sadakati kavramı ile ilişkisi incelenen kavramların dağılımına yer verilmiştir. Yayınlanmış 309 çalışmada toplam 282 farklı kavram ile marka sadakatinin ilişkisi incelenmiştir. Tablo 8.'de marka sadakati kavramı ile ilişkisi en çok incelenen kavramlar "Marka Güveni” (40), “İlişki Eğilimi” (22), "Marka Aşkı” (21), "Marka Kişiliği” (19) ve "Güven” (10) kavramlarıdır. 
Tablo 8. Lisansüstü Tezler ve Makalelerde Marka Sadakati Kavramı İle İlişkisi İncelenen Kavramların Dağılım

\begin{tabular}{|c|c|c|c|c|c|}
\hline $\begin{array}{l}\text { Sosyal } \\
\text { Sorumluluk }\end{array}$ & $\begin{array}{l}\text { Sosyal Sorumluluk(2), Kurumsal Sosyal Sorumluluk (4), Sosyal Sorumluluk } \\
\text { Projeleri (1), Kurumsal Sosyal Sorumluluk Projeleri (1), Sosyal sorumluluk } \\
\text { Suçluluğu (1) }\end{array}$ & Değer & $\begin{array}{l}\text { Alglanan Değer (13), Marka Değeri (5), Müstteri Değeri (5), Bireysel Değerler } \\
\text { (1), Tüketicic Değerleri (2), Hedonik Değer (2), Sembolik Değer (2), Algilanan } \\
\text { Parasal Değer (1) }\end{array}$ & Marka Topluluğu & 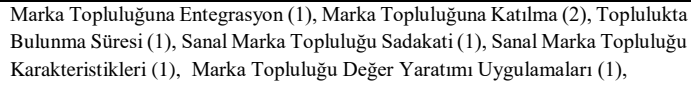 \\
\hline $\begin{array}{l}\text { Satın Alma } \\
\text { Davranışı }\end{array}$ & $\begin{array}{l}\text { Tavsiye//srar Davranıı̣ı (1), Satıı Alma Davranışı (1), Tüketici Satıı Alma } \\
\text { Davranış (2) }\end{array}$ & Kişilik & $\begin{array}{l}\text { Marka Kişiliği (19), Kisililik Özellikleri (3), Tüketici Kişilik Özellikleri (1), } \\
\text { Postmodern Kişilik Özellikleri (1) }\end{array}$ & Konumlandırma & $\begin{array}{l}\text { İşlevsel-Sembolik Konumlandırma (1), Sembolik Konumlandirma (1), İșlevsel } \\
\text { Konumlandırma (1) }\end{array}$ \\
\hline Özdeşleşme & Özdeşleşme (1), Marka özdeşleşme (2) & Etik & Etik (1), Etik Marka Algıları (1) & Sahiplik & (1), Marka Sahiplik Durumu (1) \\
\hline Güven & $\begin{array}{l}\text { Güven (10), Markaya Güven (4), Markaya Duyulan Güven (4), Marka Güveni } \\
\text { (40), Tüketici Güveni (1), Fiziki Yeterlilik/Güven (1) }\end{array}$ & İletişim & $\begin{array}{l}\text { İletişim (1), Marka İletişimi (1), Pozitif Ağıdan Ağı̆za İletiş̧im (1), Wom İletişimi } \\
\text { (1), Elektronik Ağıdan Ağıza İletişim (1), Wom (6) }\end{array}$ & Memnuniyet & $\begin{array}{l}\text { Memnuniyet (6), Tüketici Memnuniyeti (2), Müșteri Memnuniyeti (12), Marka } \\
\text { Memnuniyet (13), Servis Memnuniyeti (1) }\end{array}$ \\
\hline \multirow[t]{2}{*}{ Bağ } & $\begin{array}{l}\text { Duygusal Bağ (1), Tüketici Ille Bağ Kurma (3), Marka İle Online Bağ Kurma (1), } \\
\text { Benlik-Marka Bağı (1) }\end{array}$ & Deneyim & $\begin{array}{l}\text { Müssteri Deneyimi (4), Marka Deneyimi (11), Kullanııı Deneyimi (1), Müșteri } \\
\text { Deneyimi Yönetimi (1) }\end{array}$ & Etkileşim & Marka Etkileşimi (1), Tüketici Marka Etkileşimi (1), Sosyal Medya Etkileşimi (1) \\
\hline & Öz Benlik (1), İdeal Öz Benlik (1), Benlik İfade Eden Marka (1) & $\begin{array}{l}\text { Müssteri } \\
\text { Illişkileri }\end{array}$ & Müşteri İlişkileri Yönetimi (1), Müssteri Ilişkileri Yönetimi Performansı (1) & Performans & Marka Performansı (4), Lojistik Hizmet Performansı (1) \\
\hline Uyum & $\begin{array}{l}\text { Öz Uyum (1), İletisiimsel Uyum (1), Benlik İmajı Uyumu (2) Tüketici İmaji Ve } \\
\text { Marka İmajı Uyumu (2), Benlik-Marka İmajı Uyumu (1), Ürün Ve Marka Uyumu } \\
\text { (1), Marka Benlik Uyumu (1) }\end{array}$ & İmaj & $\begin{array}{l}\text { Marka İmajı (32), Gastronomi Marka İmajı (1), Destinasyon Marka İmajı (1), } \\
\text { Kurumsal İmaj (1), Mağaza İmaji (1), Kurususal Marka İmajı Bileşenleri (1) }\end{array}$ & İlgilenim Düzeyi & $\begin{array}{l}\text { Marka İle İlgilenim Düzeyi (1), Ürün İlgilenimi Düzeyi (1), Beklenti Düzeyi (1), } \\
\text { Ürün Bilgi Düzeyi (1), Algılanan Lojistik Hizmet Düzeyi (1) }\end{array}$ \\
\hline Tutum & $\begin{array}{l}\text { Markaya Yönelik Tutum (1), Markaya Karşı Tutum (1), Kredi Kartına Yönelik } \\
\text { Tutum (1), Retro Ürünlere Karşı Tutum (1), Helal Gida Tutumu (1) }\end{array}$ & $\begin{array}{l}\text { Sosyal } \\
\text { Medya }\end{array}$ & $\begin{array}{l}\text { Sosyal Medya Kampanyaları (1), Sosyal Medya Yorumları (1), Sosyal Medya } \\
\text { Kullanım Alışkanlikları (1), Sosyal Medya Kullanımı (2), Sosyal Medya Araçları } \\
\text { (1) }\end{array}$ & Fiyat & $\begin{array}{l}\text { Kalite ve Fiyat (1), Fiyat (3), Algılanan Fiyat (1), Hizmetin Fiyatı (1), Algılanan } \\
\text { Düşük Fiyat (1) }\end{array}$ \\
\hline Fayda & $\begin{array}{l}\text { Ürün Faydası ( 1), Marka Faydası ( 2), Algılanan Fayda (1), Rasyonel Fayda (1), } \\
\text { Duygusal Fayda (1) }\end{array}$ & İtibar & $\begin{array}{l}\text { Marka İtibarı (2), Sirket İtibarı (2), Kurumsal İtibar (2), Kurumsal İtibar Katsayıs1 } \\
\text { (2) }\end{array}$ & Kimlik & $\begin{array}{l}\text { Kimlik (1), Gerceke Öz Kimlik (1), Öz Kimlik (1), Marka Kimliği (2), } \\
\text { Tüketici-Marka Kimliği (1) }\end{array}$ \\
\hline \multirow[t]{3}{*}{ Markalama } & Duyusal Markalama (2) & & Fikir Liderliği (1) & & Ödeme Yöntemi (1) \\
\hline & Zaman Baskisı (1) & & Gözatma(1) & & Oyunlaştrma (4) \\
\hline & Etnosentrik Eğilimler (3), Tüketici Etnosentrizmi (2) & & Marka Farkındalığı (5), Çevreci Marka Farkndalı̆̆ı (1) & İlişki & Müşteri Illişkileri (1), Marka Benlik İlişkisi (1) \\
\hline \multirow[t]{2}{*}{ Marka Aşk } & Marka Aşki (21) & Kuşaklar & Yaş Kuşakları (1), X,Y,Z Kuşaklar (2) & & Aile Etkisi (1), Arkadas Grubu Onayı (1) \\
\hline & Kullanım Kolaylı̆̆ı (1) & & Digital Halkla İliskiler (1) & & Tüketici Davranış̧ndaki Değişim (1) \\
\hline
\end{tabular}


Marka Ögeleri (Marka Ad, Logosu, Slogam, Web Adresi Ve Karakteri)"(1)

Tüketici Cinsiyeti (1), Marka Cinsiyeti (1)

Markalaşma (2)

Marka Genișleme Stratejileri (1)

Marka Seçim Yönelimi (1)

Takm Aidiyeti (1)

Tüketici Yenilikçiliği (5)

Sponsorluk Sponsorluk (1)

Marka Algısı(3), Benlik Algısı (1), İtibar Algısı (1)

Batk Maliyet Yanılgisı (1)

İlişki Eğilimi (22), Affetme Eğilimi (1), Nostalji Eğilimi (1), İndirim Eğilimi (1), Statüko Eğilimi (1)

Ün

Ün/Itibar (1), Marka Ünü (3)

Psikolojik İhtiyaç (1), Psikososyal Ihtiyaç (1)

Davranıssal Sadakat Ile Tutumsal Sadakat Ölceklerinin Karșlasturluması (1)

Empati $\quad(1)$

Havayolu Firmaının İnstagram Paylaşımları (1)

\section{Kategori Genişlemesi (1)}

\section{Yaşanan Deneyim Durumu (1)}

Marka Çağrışımları (3), Marka Bilinirliği (3), Marka Özgüllüğü (3), Marka Tercihi (7), Marka Benzerliği (1), Marka Tahminlemesi (1), Marka Prestiji (1), Marka Beklentisi (2), Marka Beğenilirliği (1), Marka Bilinci (1), Marka Evangelizmi (2), Marka Kredibilitesi (1), Marka Ortaklığı (1), Marka Tutarllığı (1), Marka Dak (1), Ma (2),

\section{Tüketim}

Hedonik Tüketim Davranıııı (1), Faydacı Tüketim Davrans (1)

Azalan Bilgi Maliyetleri (1), Değistirme Maliyeti (3),

Reklamlarda Kadın İmge Kullanımı (1)

Kendini Kurgulama (1)

Marka Değerlendirmeleri (1)

Tüketim Ritüelleri (1)

Demografik Özellikler (21

Kültür (2)

Sosyal Medya Tabanlı Iletişim Faaliyetleri (1)

Beklenti (1)

Kayıptan Kaçıma (1), Belirsizlikten Kaçıma (1), Riskten Kaçımma (1)

Hata Olasilığı (1)

Alş̧veriş Skklğı 1 (1)

Sürdürülebilir İșletme Başarısı (1), Pazara Yeni Sürülen Ürünün Başarııı (1)

Personel (3)

Kafa Karıșılılğı (1)

Tüketimin Sosyal Görünürlǚğu (1)

Fiziksel Kanttlar (1), Fiziksel Olanaklar (1)

Sadakat Düzeylerini Belirleme (2), Marka Sadakati Düzeyleri (1), Mark Sadakatini Belirleyen Etmenler (1), Marka Sadakatini Etkileyen Faktörler (3) Melirleme (1)
Tiksinme Duyarllığı(1)

Kargo Hizmet Düzeyi (1), Kargo Ücreti (1)

Dört P

Müsteri Şikayet Yönetimi (1)

Kullanıcı Arabirim Tasarmı (1)

Algılanan Kurum Yetkinliği (2)

Müşteri Katılımı (1)

Pazar Pay1 (1)

Transmedya Hikayeciliği (2), Hikayeleștirme (1)

Sürü Psikolojisi (1)

Arac Özellikleri (1), Gaz İstasyonu Özellikleri (1)

Yetịskin Bağlanma Tipleri (1)

Doyum (1)

Star-Marka Stratejisi İle Yapıılmıs Televizyon Reklamları (1)

İlgi (2)

Teknik Özellikler(1)

Ürün ve Marka Özellikleri (1)

Eğitim Kadrosu

Ürün İnovasyonu (1), Ürün Kategorisi (1), Ürün Miktarnın Az Olma Algısı (1), Ürün İlgilenimi (7), Ürün Geliştirme (1), Ürün Satn Alma Kriterleri (1) 


\section{SONUÇ ve DEĞERLENDİRME}

$\mathrm{Bu}$ çalışmada 2002-2020 yılları arasında marka sadakati kavramı konusunda yayımlanan makalelerin ve lisansüstü tezlerinin bibliyometrik özelliklerinin belirlenmesi, böylece marka kavramı alanının daha yakından tanınması sağlanması ve araştırmacılara bu alanın yapısı ile ilgili bilgilerin sunulması amaçlanmıştır. Ayrıca marka sadakati kavramı ile ilişkisi araştırılan kavramlar incelenerek bu yolla elde edilecek bilgiyle marka sadakati konu alanının zaman içerisinde gösterdiği gelişmeyi gözler önüne sererek bu alanla ilgili bilimsel iletişime ilişkin çeşitli bazı bulgular elde edilmesi açısından oldukça önemlidir. Bu nedenle,18 yıllık zaman diliminde Türkiye Akademik Arşivi (Harman) veri tabanından elde edilen makaleler (141) ve Yükseköğrenim Kurulu Başkanlığı (YÖK) Ulusal Tez Merkezi veri tabanında kayıtlı doktora tezi (23), yüksek lisans tezi (145) olmak üzere toplam 309 çalışma değerlendirilmiştir. $\mathrm{Bu}$ değerlendirme bibliyometri yönteminden yararlanılarak gerçekleştirilmiş makalelerin ve lisansüstü tezlerinin yıllara göre dağılımı, üniversitesi, anabilim dalı, dili, dergi ismi, araştırma yöntemi, örnekleme seçme yöntemi, örneklem grubu ve araştırma modelinde marka sadakati kavramı ile ilişkisi incelenen kavramlar parametreleri çerçevesinde ele alınmış ve sonuçları sunulmuştur.

Marka sadakati konusuna ilişkin akademik çalışmaların özellikle son altı-yedi yılda yoğunlaştı̆g en fazla çalışmanın 2019 yılında (\% 22) yayımlandığı ulaşılan araştırma sonuçlarındandır.

Çalışma kapsamına alınan makalelerin ve lisansüstü tezlerinin en fazla Türkçe (264) dilinde yayımlanırken İngilizce (44) ve Almanca (1) dillerinde daha az yayımlandığı sonucuna ulaşılmıştır. Marka sadakati kavramı ile ilgili en fazla lisansüstü tezi yazılan üniversite Marmara üniversitesi (31) olmuştur. Bunu sırasıyla; Bahçeşehir Üniversitesi (15), İstanbul Üniversitesi (8), Beykent Üniversitesi (5) ve Gazi Üniversitesi (5) izlemiştir. Bunula birlikte lisansüstü tezlerinin en fazla "İşletme Anabilim Dalı" (100)'nda yazıldığı ulaşılan araştırma sonuçlarındandır. Bu sonuç Öcel' in (2019) ve İnce ve Uğurtürk'ün (2019) çalışmalarıyla benzerlik göstermektedir. Ayrıca bu durum marka sadakati ile ilgili çalışmaların Türkiye genelinde Üniversitelerde ve anabilim dallarında homojen olarak dağılmadığı ve çalışmaların bazı üniversitelerde ve anabilim dallarında yoğunluk gösterdiğini ifade etmektedir. Marka sadakati kavramı ile ilgili yayınlanmış makaleler içerisinde ise en fazla sırasıyla "İşletme Araştırmaları Dergisi “(6), “Süleyman Demirel Üni. İ̈BF Dergisi” (5), “Marmara Üni. Öneri Dergisi” (4) de yayınlandığı görülmektedir.

Toplam 96 farklı dergi içerisinde 67 dergide bir makale yayımlanırken 18 dergide iki, 7 dergide üç makale yayımlanmıştır. Dergilerin dağılımından da anlaşılacağı üzere marka sadakati konusunda çok farklı alanlarda yayımlar yapılmıştır.

Çalışma kapsamına alınan akademik çalışmaların çoğunluğunda Nicel yöntem (286) tercih edilirken, Nitel (15) ve Karma (8) yöntemlerinde daha az tercih edildiği elde edilen araştırma 
sonuçlarındandır. Öcel' in (2019) marka ve Bakır'ın (2013) pazarlama alanında yazılan doktora tezlerini incelediği çalışmalarında da nicel yöntemin daha fazla tercih edildiği görülmektedir.

Çalışmaların önemli bir kısmında veri toplama yöntemi olarak anket tekniği (286), örnekleme seçme yöntemi olarak da kolayda örnekleme seçme yöntemi (161) tercih edildiği sonucuna ulaşılmıştır. Ayrıca çalışmaları örneklem gruplarına göre incelediğimizde örneklem grupları içerisinde daha çok tüketicilerin (223) yer aldığı, ardından öğrencilerin (61) ve yöneticilerin (6) incelendiği sonucuna ulaşı1mıştır. Bu araştırma sonucu, İnce ve Uğurtürk'ün (2019) çalışmasında en çok anket tekniği kullanıldığ 1 ve örneklem grubu olarak tüketicilerin ve öğrencilerin tercih edildiği sonucuyla örtüşmektedir.

Akademik çalışmaların marka sadakati ile ilişkisi incelenen kavramlar itibariyle incelenmesi neticesinde yayımlanmış 309 çalışmada toplam 282 farklı kavram ile marka sadakatinin ilişkisi incelenmiştir. Bununla birlikte marka sadakati kavramı ile ilişkisi en çok incelenen kavramlar "Marka Güveni” (40) olmakla birlikte onu "İlişki Eğilimi”" (22), "Marka Aşkı” (21), "Marka Kişiliği” (19) ve "Güven" (10) kavramlarının izlediği görülmektedir.

İncelemeye alınan lisansüstü tezlerinin ve makalelerin Türkiye Akademik Arşivi (Harman) ve Yükseköğrenim Kurulu Başkanlığı (YÖK) Ulusal Tez Merkezi ile sınırlı tutulması bu çalışmanın bir sınırlılığı olarak değerlendirilebilir. Kongre bildirileri gibi diğer çalışmaların da araştırma kapsamına dâhil edilerek gerçekleştirilebilecek bibliyometri çalışmaları daha derinlemesine bulgular sunabilir. Öte yandan benzer bir çalışmanın ilerleyen dönemde yinelenmesi, elde edilen bulguların bu çalışmadan elde edilen bulgularla, dönemler itibariyle karşılaştırılmasına olanak tanıyabilir.

\section{Ek beyan}

- " 1. yazar \%60 oranında, 2. yazar \%40 oranında katkı sağlamıştır."

- Makalenin tüm süreçlerinde JTM'ın araştırma ve yayın etiği ilkelerine uygun olarak hareket edilmiştir."

- Bu çalışmada herhangi bir potansiyel çıkar çatışması bulunmamaktadır.

\section{KAYNAKÇA}

Al, U., (2008). Türkiye'nin Bilimsel Yayın Politikası: Atıf Dizinlerine Dayalı Bibliyometrik Bir Yaklaşım, (Yayımlanmamış Doktora tezi). Ankara Üniversitesi, Sosyal Bilimler Enstitüsü, Ankara

Aliyev, F., Urkmez, T., ve Wagner, R.,(2019). A Comprehensive Look At Luxury Brand Marketing Research From 2000 To 2016: A Bibliometric Study And Content Analysis. Management Review Quarterly, 69:233-264.

Aaker, David, A. (1991). Managing Brand Equity-Capatilizing on the Value of a Brand Name. New York: The Free Press. 
Avasthi, S., De, T., ve Dikkatwar, R., (2021). New Paradıgm Of Brandıng In Social Media-A Bibliometric Analysis. International Journal of Modern Agriculture, 10 (2), 521-540.

Bakır, Ozan, N. (2013). Pazarlama Alanında Yapılan Doktora Tezlerinin Kategorik Olarak Değerlendirilmesi (1994-2012). Journal of Marmara University Social Sciences Institute/Öneri, 10 (40).

Barahona, I., Hernández, D. M., Pérez-Villarreal, H. H., ve del Pilar Martínez-Ruíz, M. (2018). Identifying Research Topics in Marketing Science Along the Past Decade: A Content Analysis. Scientometrics, 117(1), 293-312.

Bennett, R. ve Rundle-Thiele, S. (2005). The Brand Loyalty Life Cycle: Implications for Marketers. Journal of Brand Management, 12 (4), 252.

Berkman, A. Ü., ve Kozan, K. (1979). Amme Idaresi Dergisi'nde Yayınlanan Makaleler Üzerine Bir Inceleme. Amme İdaresi Dergisi, 12 (1), 9-26.

Borgman, C. ve Furner, J. (1990). Scholarly Communication and Bibliometrics: Sage Newbury Park, CA,

Boora, K. K., \& Singh, H. (2011). Customer loyalty and its antecedents: a conceptual framework understanding e-marketing-optimization of resources. Asia Pacific Journal of Research in Business Management, 2(1), 151-164.

Bozyiğit, S. ve Yaşa, E. (2012). Araştırmacıların Pazarlama Alanına Bilimsel Katkıları: Pazarlama Konusunda Yapılan Lisansüstü Tezlere İlişkin Bir Araştırma, 17. Ulusal Pazarlama Kongresi Kitapçığı, 18- 21 Ekim, 55-74.

Chabowski, B. R., Samiee, S., ve Hult, G. T. M. (2013). A Bibliometric Analysis Of The Global Branding Literature and A Research Agenda. Journal Of International Business Studies, 44(6), 622-634.

Cătoiu, I., Gârdan, D.A. ve Geangu, I.P. (2012). Customer loyalty - specific Features Of Retail Activity In Bucharest. Annales Universitatis Apulensis Series Oeconomica, 14(1), 278-285.

Çatı, Ö. ve Öcel, Y., (2018). Türkiye'de Pazarlama İle İlgili Yayınlanan Makalelerin Bibliyometrik İncelenmesi. İşletme Araştırmaları Dergisi, 10(3), 508-519.

Cunningham, R.M. (1956). Brand Loyalty - What, Where, How much?. Harvard Business Review, 34 (1), 116-128,

Dubina, O., Us, Y., Pimonenko, T., ve Lyulyov, O. (2020). Customer Loyalty to Bank Services: The Bibliometric Analysis. Virtual Economics, 3(3), 52-66.

Ferrel, O. C. ve Hartline, M. D. (2011). Marketing Strategy (5th ed). Mason, OH, USA: Cengage Learning.

Fetscherin, M., ve Heinrich, D., (2014). Consumer brand relationships research: A bibliometric citation metaanalysis. Journal of Business Research, 68 (2), 380-390.

Fournier, S. ve Yao, J.Ül., (1997). Reviving Brand Loyalty: A Reconceptualization within the Framework of Consumer-Brand Relationships. International Journal of Research in Marketing, 14, 5, 451-472.

Gary Holden DSW, Gary Rosenberg PhD ve Kathleen Barker PhD (2005). Tracing Thought Through Time and Space. Social Work in Health Care, 41: 3-4, 1-34,

Guest, 1. (1944). A Study of Brand Loyalty. Journal of Applied Psychology, 28, 16-27,

Gülmez, M., Yalçıntaş, D., Kurtulgan, A., ve Özbay, M., (2019). Türkiye'de Pazarlama Alanında Yazılan Doktora Tezlerinin İncelenmesi. Çağ Üniversitesi Sosyal Bilimler Dergisi, 16 (1), 59-69. 
Gürbüz, C., ve Bozkurt, Ö. Ç. (2018). Pazarlama ve Pazarlama Araştırmaları Dergisi’nin Bibliyometrik Analizi. Adnan Menderes Üniversitesi Sosyal Bilimler Enstitüsü Dergisi, 5(3), 1-23.

Hall, C. M. (2011). Publish and Perish? Bibliometric Analysis, Journal Ranking and The Assessment Of Research Quality in Tourism. Tourism Management, 32, 16- 27

Heberger, E. Anne - Christie, A. Christina - Alkin, C. Marvin (2010). A Bibliometric Analysis of the Academic Influences of and on Evaluation Theorists' Published Works. American Journal of Evaluation, 31(1), 24-44.

Jacoby, J. (1971). Brand loyalty: A conceptual definition. Proceedings of the Annual Convention of the American Psychological Association, 6 (Pt. 2), 655-656.

Jacoby, J., and Kyner, D., (1973). Brand loyalty vs. repeat purchasing behavior. Journal of Marketing Research, 10, 1-9.

İnce, M., ve Uygurtürk, H., (2019), Marka Kimliği, Marka Kişiliği, Marka İmajı Ve Marka Konumlandırma Alanında Yapılan Lisansüstü Tezlere Yönelik Bir İnceleme. Karabük Üniversitesi Sosyal Bilimler Enstitüsü Dergisi, 9 (1), 224-240.

Kabiraj, S., ve Shanmugan, J. (2011). Development of a Conceptual Framework for Brand Loyalty: A EuroMediterranean Perspective. Journal of Brand Management, 18(4/5), 285-299.

Khiste, G., ve Paithankar, R. R. (2017). Analysis of Bibliometric Term in Scopus. International Journal of Library Science and Information Management, 3(3), 81-88.

Koehler, W. (2001). Information science as "Little Science": The implications of a bibliometric analysis of the Journal of the American Society for Information Science. Scientometrics, 51(1):117-132

Kozak, N. (1994). Anatolia: Turizm Araştırmaları Dergisi'nde yayımlanan yazılar üzerine bir İnceleme. Anatolia: Turizm Araştırmaları Dergisi, 5 (Aralık), 22-33.

Khurana, A. ve Kumar, V.V R. (2019). Two Decades of Brand Personality: A Bibliometric Review of the Dimensions. SCMS Journal of Indian Management; Kochi, 16(2), 103-117.

Law, R., ve Cheung, P. (2008). An analysis of publications in leading tourism journals and its implications. Journal of China Tourism Research, 4, 78 - 97.

Law, R., ve Chon, K. (2007). Evaluating research performance in tourism and hospitality: The perspective of university program heads. Tourism Management, 28, 1203- 1211.

Llanos-Herrera, G. R., ve Merigo, J. M. (2019). Overview of brand personality research with bibliometric indicators. Kybernetes, 48 (3), 546-569.

Lu Ting Pong, J . ve Tang Pui Yee, E .( 2001 ) 'An integrated model of service loyalty ', Academy of Business \&Administrative Sciences 2001 International Conferences, Brussels, Belgium held on 23rd - 25th July, 2001.

Majerova, J., Gajanova, L., ve Nadanyiova, M., (2021). A Bibliometric Analysis of Branding Trends: Does Irrationality Really Matter?. SHS Web of Conferences, 91 (2).

Moretta Tartaglione, A., Cavacece, Y., Russo, G., ve Granata, G. (2019). A systematic mapping study on customer loyalty and brand management. Administrative Sciences, 9(1), 8. 
Neme-Chaves, S. R., ve Rodríguez-González, L. Y. (2019). Un análisis bibliométrico del brand equity 19912018//A bibliometric analysis of brand equity 1991-2018. Revista de Métodos Cuantitativos para la Economía y la Empresa, 28, 364-380.

Odin, Y, Nathalie, N., Odin, ve Pierre, V-F., (2001). Conceptual and Operational Aspects of Brand Loyalty: An Empirical Investigation. Journal of Business Research, 53 (2), 75-84.

Oliver, R.L. (1999). Whence Consumer Loyalty? Journal of Marketing, 63, 33-44.

Oliver, R.L. (2010). Satisfaction: A Behavioral Perspective on the Consumer. 2.Basım, Londra: Routledge

Osareh, F. (1996). Bibliometrics, citation analysis and co-citation analysis: A review of literature I. Libri, $46,149-158$.

Öcel, Y., (2019), Türkiye'de Marka İle İlgili Yazılan Doktora Tezlerinin Bibliyometrik İncelenmesi. Uluslararası Batı Karadeniz Sosyal ve Beşeri Bilimler Dergisi, 3(1): 38-49.

Pritchard, A. (1969). Statistical bibliography or bibliometrics? Journal of Documentation, 25:348-349.

Punniyamoorthy, M. ve Prasanna Mohan Raj, m., (2007). An Empirical Model For Brand Loyalty Measurement. Journal Targeting, Measurement and Analysis for Marketing, 15 (4), 222-233.

Radler, V. M. (2018). 20 Years of brand personality: a bibliometric review and research agenda. Journal of Brand Management, 25(4), 370-383.

Rundle-Thiele, s. (2005), Exploring loyal qualities: assessing survey-based loyalty measures, Journal of Services Marketing, 19 (7), 492-500.

Salam, M.D. (2020). Brand experience: a review of 39 years of research development. TIJAB (The International Journal of Applied Business), 4(2), 157-167.

Sepulcri, L. M. C. B., Mainardes, E. W., ve Belchior, C. C. (2020). Nonprofit branding: a bibliometric analysis. Journal of Product \& Brand Management, 29 (5), 655-673.

Sheth, Jagdish N., Park, C. Whan, (1974). A Theory of Multidimensional Brand Loyalty". Advances in Consumer Research, 1 (1), 449-459.

Siemieniako, D. (2018). Bibliometric analysis of scientific research on customer loyalty in the business-tobusiness context. Handel Wewnętrzny, 5 (376), 257-267.

Sivarajah, R. ve Sritharan, V. (2014). Influence Of Moderatıng Varıables On Attachment, Brand Trust And Loyalty Relationship. International Journal of Economics, Commerce and Management, 2(4), 1-14.

Ulu, S., ve Akdağ, M., (2015). Dergilerde Yayınlanan Hakem Denetimli Makalelerin Bibliyometrik Profili: Selçuk İletişim Örneği. Selçuk İletişim, 9 (1), 5-21.

Yalçın, H. (2010). Millî Folklor Dergisi'nin Bibliyometrik Profili (2007-2009). Millî Folklor, (22) 85, 205211.

Yoo, B. , Donthu , N., ve Lee, S., (2000). An Examination of Selected Marketing Mix Elements and Brand Equity. Journal of the Academy of Marketing Science, 28 (2), 195-211.

Zencir E ve Kozak N (2012) Sosyal Bilimler Enstitü Dergileri'nde yayımlanan Turizm Makalelerinin Bibliyometrik Profili (2000-2010), N Kozak ve M Yeşiltaş (Yay. Haz), VI. Lisansüstü Turizm Öğrencileri Araştırma Kongresi Bildiri Kitabı, 673-685. 
Zhu, Q., Martins, R. A., Shah, P., ve Sarkis, J. (2021). A Bibliometric Review of Brand and Product Deletion Research: Setting a Research Agenda. IEEE Transactions on Engineering Management,1-21. 